\title{
THE PARTNERSHIP MODEL OF THE RELATIONSHIP BETWEEN TAX ADMINISTRATORS AND TAX PRACTITIONERS: DRIVERS, CHALLENGES AND PROSPECTS
}

\section{By Dr Mark Burton* and Dr Justin Dabner ${ }^{\dagger}$}

This article reviews the history of the partnership model of tax administration and the challenges that the model has encountered, and also reflects upon the prospects of the model. Avenues for further critical reflection upon the operation of the partnership model are then suggested. with a view to the enhancement of the model.

\section{INTRODUCTION}

Drawing upon the theory of responsive regulation, in the 1990s the Australian Commissioner of Taxation ('the Commissioner') expressed the partnership model of tax administration. Shortly afterwards, the New Zealand Inland Revenue Commissioner joined this shift to (what has been cast as) the way forward in meeting the demands upon a tax administration in a modern, open democratic society. After something like a decade since the adoption of this new model of tax administration, it is appropriate to review its history, the challenges that have been encountered and also to reflect upon the prospects of the partnership model. The purpose of this article is to undertake this task and to suggest avenues for further critical reflection upon the operation of the partnership model with a view to its enhancement.

Part 1 of this article identifies and elaborates upon the two models of tax administration that are evident in recent Australian and New Zealand history: the adversarial model and the partnership

\footnotetext{
${ }^{*}$ Law School, University of Canberra.

${ }^{\dagger}$ School of Law, James Cook University, Cairns Campus.
} 


\section{THE PARTNERSHIP MODEL}

model. Part 2 of the article reviews the drivers which prompted the paradigm shift in New Zealand and Australia from an adversarial model to a partnership model. Part 3 of the article identifies tensions within the partnership model and discusses the practical emanations of these tensions, evident in the operation of the partnership model.

\section{BACKGROUND}

\subsection{Different Approaches to Tax Administration}

There are different approaches to conceptualising the role of the tax administrator vis-à-vis tax advisers which emerge from different perspectives regarding the relationship between the individual and the state. From the perspective of liberal individualism, taxation might be seen to be a compulsory expropriation of a person's private property, ${ }^{1}$ and so from this perspective the individual is entitled to minimise by legal means the extent to which the state 'puts its shovel' into the individual's store of wealth. ' 'Of course I am minimising my tax, and if anybody in this country doesn't minimise their tax they want their heads read', the late Kerry Packer famously opined in response to a question before a Senate Committee. From this individualist perspective, the ethical obligation of a tax adviser is to uphold the law, which means that the adviser ensures that their client pays no more tax than is required by law. ${ }^{3}$ The state is cast as a revenue maximiser pursuing its 'self'-interest, ${ }^{4}$ or at least the self-interest of state agents. ${ }^{5}$ Thus, tax administrator and tax adviser

\footnotetext{
${ }^{1}$ For a critique of this mainstream characterisation of the nature of taxation, see Liam Murphy and Thomas Nagel, The Myth of Ownership (2002).

${ }^{2}$ Re Vicars (decd) (1945) 45 SR (NSW) 85.

${ }^{3}$ See, eg, Geoffrey de Q Walker, 'Tax Complexity and the Rule of Law' in Peter Saunders (ed), Taxploitation (2006) 87.

${ }^{4}$ Geoffrey Brennan, 'Public Choice and Taxation: Leviathan after Twenty Years' in Richard Krever (ed), Tax Conversations: A Guide to the Key Issues in the Tax Reform Debate (1997) 87, 100. See also Geoffrey Brennan and James Buchanan, The Power to Tax (1980) 26ff; Margaret Levi, Of Rule and Revenue (1988).

${ }^{5}$ Sam Peltzman, 'Constituent Interest and Congressional Voting' (1984) 27 Journal of Law and Economics 181; D Mayhew, The Electoral Connection (1974); Morris Fiorina, Congress: Keystone of the Washington Establishment (1977).
} 
pursue mutually inconsistent objectives in an adversarial relationship akin to the relationship between opposing counsel in a common law system. Under this model, the tax authority would administer and apply the law with a view to maximising government revenue and pursuing government policy whilst the profession would seek to minimise the tax liabilities of its clients by employing tax planning techniques, asserting pro-taxpayer interpretations of the tax law, or both of the above.

A vastly different characterisation of the relationship between tax administrator and tax adviser takes Rousseau's concept of the 'general will' as its starting point. From this perspective, the individual and state are not a dichotomy but a unity framed upon a common identity. ${ }^{6}$ On this view, the tax administrator and the tax profession comprise a partnership which pursues fulfilment of the 'general will' expressed in the community's tax laws. Such a partnership may experience friction, but the parties strive to minimise conflict and seek to achieve negotiated positions and 'practical' outcomes consistent with the 'general will'.

\subsection{History}

The regulatory history of both the Australian Taxation Office ('the ATO') and the New Zealand Inland Revenue Department ('the IRD') reflects the various regulatory theories. By the end of the $20^{\text {th }}$ century there were clear indications of dissatisfaction with the extant tax administration process in both Australia and New Zealand. In Australia, the Cash Economy Taskforce, ${ }^{7}$ the Ralph Review of Business Taxation $^{8}$ and senior officers of the ATO openly

${ }^{6}$ Jean-Jacques Rousseau, The Social Contract, or Principles of Political Right (1762) bk 1, ch 6.

7 Australian Taxation Office, Improving Tax Compliance in the Cash Economy (1998) 11.

$8 \mathrm{~J}$ Ralph, R Albert and B Joss, Review of Business Taxation: A Tax System Redesigned - More Certain, Equitable and Durable (1999) 147 (calling for a less adversarial approach to dispute resolution). 


\section{THE PARTNERSHIP MODEL}

contemplated a new direction in tax administration. ${ }^{9}$ Since then the transition to a model of cooperative compliance has not always been smooth: in 2002 the ATO's relationship with the profession reached an all time low. ${ }^{10}$ However, such tribulations have only served to strengthen the apparent resolve of senior officers of the ATO to embrace a cooperative approach to taxpayers and their advisers. ${ }^{11}$ Such statements are not mere verbiage: there has been a demonstrable shift in the approach adopted by the ATO in its dealings with the profession. The type of information it gathers, ${ }^{12}$ the preparedness to publicly disseminate information germane to both taxpayer compliance and the accountability of the ATO, ${ }^{13}$ the breadth of its consultative arrangements with tax advisers ${ }^{14}$ and also its efforts to ease the administrative burden of tax advisers ${ }^{15}$ are all indicative of this paradigm shift.

9 See, eg, Michael Carmody, 'Future Directions in Tax Administration' (Paper presented at the Third International Conference on Tax Administration, Sydney, 17 April 1998).

${ }^{10}$ For discussion of which see Australian National Audit Office, The Australian Taxation Office's Management of Its Relationship with Tax Practitioners, Report No 19 (2003). For the far more positive follow-up report, see Australian National Audit Office, The Australian Taxation Office's Management of Its Relationship with Tax Practitioners: Follow-Up Audit, Auditor-General Audit Report No 30 (2007).

11 Discussed in Justin Dabner, 'Partners or Combatants: A Review of the Relationship of the Australian Tax Office with the Tax Advising Profession' (Paper presented at the $19^{\text {th }}$ Annual Australasian Tax Teachers Association Conference, Brisbane, 23 January 2007).

12 See, eg, Australian Taxation Office, Biannual Tracking of Tax Agents Perceptions' of Service and Usage of Channels: Wave 14 (October 2006) (2007) Australian Government <http://www.ato.gov.au/print.asp?doc=/content/00091816. htm>.

${ }^{13}$ Australian Taxation Office, ATO Compliance Program 2006/07 (2006).

14 For an overview of many of the Commissioner's consultative forums, see Australian Taxation Office, Stakeholder Consultation Overview (2008) Australian Government <http://www.ato.gov.au/default.asp?menu=6540>. At the time of writing, the most recent initiative is the appointment of senior regional representatives to consult with tax practitioners to discuss serious issues or systemic problems.

${ }^{15}$ Recently reiterated by the Commissioner, Michael D'Ascenzo. See Michael D'Ascenzo, 'A Partnership Based on Trust and Respect' (Speech delivered at the 
In terms of its relationship with tax advisers, on many occasions the ATO has expressed a desire to more fully establish a partnership approach with the profession. ${ }^{16}$ For $2006-07$, the ATO has included in its description of its compliance program a new section focusing entirely on how it sees its relationship with tax practitioners. Essentially the chapter is laden with commitments to continue to consult, co-design and co-operate in all dealings impacting on tax practitioners. ${ }^{17}$

There are also clear signs that tax practitioners have reciprocated. Thus the President of the Taxation Institute of Australia commented in the Institute's journal of August 2006 that it was critical 'to foster an open and mature relationship with all levels of the ATO to ensure the best possible outcomes from our consultations' ${ }^{18}$

The experience in New Zealand would appear to be very similar. During the 1990s the relationship between the IRD and the profession became strained with both a Select Committee Report of 1996 and a Finance and Expenditure Committee Report of $1999^{19}$ identifying problems in the relationship. Then, in 2001, the IRD embraced the responsive regulation or compliance model, ${ }^{20}$

National Institute of Accountants Board Meeting, Canberra, 8 May 2007); Michael D'Ascenzo, 'Working with the Tax Profession' (Speech delivered at the $22^{\text {nd }}$ National Convention of the Taxation Institute of Australia, Hobart, 15 March 2007); Michael D'Ascenzo, 'A New Relationship with the Tax Profession' (Speech delivered at the $21^{\text {st }}$ National Convention of the Taxation Institute of Australia, Gold Coast, 6 April 2006); Michael D'Ascenzo, 'Living Our Values' (Speech delivered at the $7^{\text {th }}$ International Tax Administration Conference, Sydney, 20 April 2006); Michael D'Ascenzo, 'Relationships between Tax Administrators and Tax Agents/Taxpayers' (Presentation delivered at the Asia-Oceania Consultants Association General Meeting, Manila, 11 November 2005).

${ }^{16}$ See the material cited at $n 15$, above.

${ }_{17}$ Australian Taxation Office, Compliance Program, above n 13, 72-8.

18 Andrew Mills, 'President's Report: Tax Transparency - Consulting with the ATO' (2006) 40(8) Taxation in Australia 65.

19 New Zealand, Inquiry into the Powers and Operations of the Inland Revenue Department, Parl Paper No 1.3 (1999).

${ }^{20}$ Discussed in Inland Revenue Department, New Zealand Inland Revenue: Annual Report 2006 (2006) pt 3. 


\section{THE PARTNERSHIP MODEL}

established a taxpayers' Charter ${ }^{21}$ and in its five year business plan identified a cooperative future and reiterated its commitment to the compliance model and Charter. ${ }^{22}$ The following year it commenced

an industry partnerships program ${ }^{23}$ and in 2003 received a favourable Auditor-General's report on its taxpayer audit strategy. ${ }^{24}$

As part of these developments, the IRD began to nurture its relationship with the profession by projecting a more collaborative approach. In a speech by the Deputy Commissioner of Business Development and Systems in October 2003, the IRD acknowledged the change in the role being played by both it and the profession and the importance of working together. ${ }^{25}$

\subsection{Why the Paradigm Shift? Drivers for the Introduction of Responsive Regulation}

The significance of this paradigm shift in Australasian tax administration cannot be understated: it is exceptional by international standards. Mention of a tax administrator and tax adviser 'partnership' in Canada, for example, prompts a startled look followed by guffaws of polite laughter (and, perhaps, the unspoken thought of 'how strange these Antipodeans are').

${ }^{21}$ Available at Inland Revenue Department, Our Commitment to the Community: Inland Revenue Charter (2008) <http://www.ird.govt.nz/aboutir/commitment/ aboutir-charter.html>.

${ }^{22}$ Inland Revenue Department, Inland Revenue Business Plan: The Way Forward 2001 Onwards (2001), recently updated in Inland Revenue Department, Inland Revenue Business Plan: Our Way Forward - 2006 to 2011 (2006).

${ }^{23}$ Discussed in Inland Revenue Department, New Zealand Inland Revenue: Annual Report 2005 (2005) pt 3.

${ }^{24}$ Controller and Auditor-General, Report of the Controller and Auditor-General: Inland Revenue Department - Performance of Taxpayer Audit (2003). Also see the follow-up audit in Controller and Auditor-General, Inland Revenue Department: Performance of Taxpayer Audit - Follow-Up Audit (2006).

25 Colin MacDonald, 'The Tax Profession's Changing Interface with Inland Revenue' (Speech delivered at the 2003 Tax Conference of the Institute of Chartered Accountants of New Zealand, Christchurch, 10 October 2003). 
What prompted such a dramatic shift in Australia and New Zealand when other tax administrations encountered similar difficulties but have not embarked upon such an ambitious reorientation? There will be many causes for such a change. Ideological background, the institutional environment, 'material' influences such as technological capacity, interest groups and individual policy entrepreneurs all simultaneously shape the perception of what is normal and what is possible, and therefore shape and stretch the tax administration at all levels across multiple sites.

Detailed consideration of the causes of the introduction of the cooperative compliance model in Australasia is beyond the scope of this article. However, for the purposes of this article it is useful to identify the ideological significance of neo-liberalism during the latter part of the $20^{\text {th }}$ century and its influence with respect to the adoption of responsive regulation. As with many 'isms', there are various definitions of neo-liberalism. However, for present purposes suffice to say that the 1980s saw a resurgence of the view that Adam Smith's 'invisible hand' of the market should displace, wherever possible, the heavy hand of government regulation. ${ }^{26}$ This view was in the ascendancy from the $1980 \mathrm{~s}$, when the centralised regulatory power of the welfare state was perceived increasingly to suffer from a legitimation crisis. ${ }^{27}$ The neo-liberal response to this perceived crisis was to argue that the nature and extent of state activity should be reduced, a view which was promoted by various well-funded lobby groups including, in Australia, the Institute of Public Affairs. ${ }^{28}$

The purpose of this Part of the article is to lay the groundwork for the argument that responsive regulation was considered to offer the best model for mediating the conflicting imperatives of emergent

\footnotetext{
${ }^{26}$ Milton Friedman, Capitalism and Freedom (1962); Milton Friedman, Freedom to Choose (1980). Friedrich Hayek's work was 'rediscovered' and is a prominent component of the neo-liberal literature: Friedrich Hayek, The Road to Serfdom (first published 1945, 2005 ed).

${ }^{27}$ See, eg, Friedman, Freedom to Choose, above n 26, chs 9-10.

${ }^{28}$ Clive Hamilton and Sarah Maddison, Silencing Dissent (2007).
} 


\section{THE PARTNERSHIP MODEL}

neo-liberalism and maintenance of the fiscal foundations of the welfare state. These imperatives included tax system efficiency and tax system integrity. This is not to suggest that responsive regulation was an offshoot of neo-liberal ideology and nor was it necessarily a doctrine which was advocated by neo-liberals. Rather, the thesis of this Part of the article is that responsive regulation offered a response to the challenges of tax administration which was palatable to a broad cross-section of the community, including those who adopted the emergent neo-liberal discourse. However, in Part 3 of this article it will be argued that this synthesis of welfarist and neo-liberal visions within the one model of tax administration has engendered systemic instability.

\subsubsection{Neo-Liberalism and the Small State Imperative}

One aspect of neo-liberal discourse was a distrust of government and, hence, a preference for small government. In terms of tax administration, an extreme example of this neo-liberal preference for private markets over public regulation was apparently considered during the preparation of the British Conservative Party election manifesto of $1997 .{ }^{29}$ However, while such an extreme has not been adopted in Australia or New Zealand, the model of responsive regulation promised a pared back, efficient tax administration which expended fewer resources by promoting voluntary compliance with taxation laws.

\subsubsection{Open Government}

The distrust of government, and the perceived crisis of legitimacy which gathered strength from the late 1970s, contributed to calls for government which was more open and accountable. ${ }^{30}$ The

${ }^{29}$ David Hencke, 'Secret Plan to Sell Off Tax System', The Guardian (London), 28 January 1997, 1. The thrust of Hencke's claim was denied by Conservative government Ministers: 'No Tory Plans to Privatise Tax Man,' The Herald (Glasgow), 29 January 1997, 6.

30 Thomas McGarity, Reinventing Rationality: The Role of Regulatory Analysis in the Federal Bureaucracy (1991) ch 2. 
erstwhile faith in an underlying moral consensus uniting a society ${ }^{31}$ or the rationality of bureaucratic actors ${ }^{32}$ (or in both of these ideals) were no longer considered sufficient justification for letting regulators get on with their work of regulating. Across the political spectrum, there were calls for more open and accountable government, such that participants in the 'political market' (for example, electors) might make informed decisions regarding their political preferences. ${ }^{33}$

From the 1970s the emergent neo-liberal discourse had challenged the role of 'unaccountable' bureaucrats in the creation and administration of law. ${ }^{34}$ Responsive regulation answered this call for open government by promising a regulatory process framed in terms of a partnership between regulators and the community. ${ }^{35}$ This partnership incorporated the participation of community representatives in regulatory processes and, moreover, entailed the provision of substantial information and assistance to members of the public in assisting them to understand and comply with the law.

\subsubsection{Global Tax Competition and Tax Administration}

Neo-liberalism has also prompted a reorientation of the perceived role of government as architect of the framework within which efficient private markets operate. ${ }^{36}$ Within this discourse, a

\footnotetext{
${ }^{31}$ Seymour Lipset, Political Man (1963).

32 Founded upon Weber's proposition that bureaucratic rationality offered the strongest path to legitimation of state action: Max Weber, Economy and Society (1978) 973.

${ }^{33}$ Organisation for Economic Co-operation and Development, Citizens as Partners (2001).

34 Geoffrey de Q Walker, The Rule of Law: Foundation of Constitutional Democracy (1988); Geoffrey de Q Walker, The Tax Wilderness: How to Restore the Rule of Law (2004).

${ }^{35}$ As originally conceived, this entailed the adoption of a tripartite regulatory model involving regulator, regulatee and a community representative: Ian Ayres and John Braithwaite, Responsive Regulation: Transcending the Deregulation Debate (1992) $57-8$.

${ }^{36}$ For a discussion of this point, see David Held, Models of Democracy $\left(3^{\text {rd }}\right.$ ed, 2006) 170.
} 


\section{THE PARTNERSHIP MODEL}

country's tax system is less the bureaucratic machinery of a sovereign state and more one facet of a state's competition for global capital and human resources. Thus, the Ralph Review of Business Taxation specifically referred to global tax competition as one driver of business tax reform, ${ }^{37}$ while more recently a similar imperative was expressly referred to in the announcement of New Zealand's International Tax Review. ${ }^{38}$

In terms of tax administration, responsive regulation promised residents of foreign countries a lower tax risk with respect to their Australian or New Zealand income: as long as they had genuinely attempted to comply with the law they would not encounter unexpected, retrospective tax penalties. Threats of capital or human resource flight (or both) are therefore one driver of a non-adversarial relationship between the collecting authority and taxpayers or tax advisers. $^{39}$

\subsubsection{Emergence of Risk Management as a Supplementary Discourse to Legitimate Tax Administration}

A fourth reason for the shift in tax administration which can be attributed to neo-liberal ideology is the enhanced status of the discourse of risk management. Weber suggested that the modern age, having eaten of the tree of knowledge, sought legitimacy in rationalised bureaucratic action. ${ }^{40}$ However, it is doubtful that the legitimation of tax systems is based solely upon one narrative such as rationalised bureaucratic action. Rather, it is more likely that bureaucratic legitimacy is founded upon several pillars, with the morality of law (also referred to as 'substantive legitimacy'), legal formalism (embodied in the rule of law) and the neo-liberal discourse

\footnotetext{
${ }^{37}$ Ralph, Albert and Joss, above n 8, 9.

${ }^{38}$ New Zealand Inland Revenue Department, New Zealand's International Tax Review: A Direction for Change (2006) 1.

39 There is evidence that punitive tax enforcement may encourage multinationals to move offshore. See Robert Lee, Where Tax Rates Fall, Multinationals Follow (2006) Tax-News.com <www.tax-news.com/asp/story/story_print.asp?storyname= $23681>$.

${ }^{40}$ Weber, above n 32 .
} 
of 'economic man' (embodied in the narrative of 'risk management') being three that are discernible in the official literature.

\subsubsection{Substantive Legitimacy}

The narrative of substantive legitimacy asserts an ethical obligation to pay tax, framed in terms of taxes being what we pay for a civilised society ${ }^{41}$ and also 'paying a fair share'. ${ }^{42}$ However, for this narrative to generate legitimacy there must be a consensus on what a civilised society means or what a 'fair share' means (assuming that 'fair share' has a meaning independent from that demanded by law). However, although there was a widely held perception of social consensus during the $1950 \mathrm{~s}$ and $1960 \mathrm{~s},{ }^{43}$ this has been displaced by alternate political theories which take as their starting point some version of systemic dysfunction or disequilibrium. In no small way, the individualism which underpins the neo-liberal critique of the modern welfare state added significant momentum to this late $20^{\text {th }}$ century angst regarding the excesses of the state in promoting a particular social vision. This is not to say that claims of substantive legitimacy of tax systems have been discarded, but rather that such claims do not win universal assent and therefore form an inadequate foundation for legitimacy and hence voluntary compliance.

\subsubsection{Rule of Law and Source of Legitimacy}

The second source of bureaucratic legitimacy can be found in the rule of law discourse. Despite continual challenge to the validity of premises underpinning the rule of law, the assumption of determinate law continues to underpin the rule of law and the rule of law remains the dominant legal discourse. It may be that the prospect of indeterminate law, anathema to liberal legalism, is just too horrific

\footnotetext{
41 A recent judicial expression of this proposition may be found in Spotless $v$ Federal Commissioner of Taxation (1996) 96 ATC 5201, 5206.

42 Michael D'Ascenzo, 'Creating a Community First Culture in the Tax Office' (Speech delivered to the Australian Public Service Commission Leadership Development Network, Canberra, 15 November 2006).

${ }^{43}$ See, eg, Lipset, above n 31.
} 


\section{THE PARTNERSHIP MODEL}

for the collective psyche to contemplate: we want to believe in the neat ordering of the social world under the rule of law. Here, the hand of neo-liberalism may be discerned: determinate law applied prospectively is one of the preconditions to efficient allocative decisions made within private markets. It is therefore no surprise that tax administrations affirm their role as law appliers rather than law makers: their job is to apply 'the law' without fear or favour.

However, by the late $20^{\text {th }}$ century the descriptive validity of these justifications for bureaucratic action had come under challenge. The existence of administrative discretions, ${ }^{44}$ the propensity of tax administrators to wield big sticks upon ordinary taxpayers while treating well-resourced taxpayers more flexibly ${ }^{45}$ and the perceived unfairness of such rationalised justice ${ }^{46}$ all pointed to a reappraisal of the role of bureaucratic rationality grounded upon the rule of law. Responsive regulation promised to restore the rule of law by enabling tax officers to select the most appropriate device for achieving the legislative purpose. Thus, for those who adhere to the rule of law and who accept that the legislative purpose underpins an acceptable interpretation of that rule, responsive regulation offered a desirable administrative strategy.

\subsubsection{Risk Management}

However, for others who had eaten of the tree of knowledge, the rule of law with its assumption of legal determinacy was less satisfying as a justification for bureaucratic action. A modern application of Weber's thesis would suggest that tax administrators would strive to promote legitimacy by extolling their professionalism. Here, the neo-liberal preference for private markets as efficient resource allocators can be discerned in the emergent bureaucratic discourse of risk management and meta-risk

\footnotetext{
${ }^{44}$ Joint Committee of Public Accounts, Commonwealth Parliament, An Assessment of Tax (1993); de Q Walker, Rule of Law, above n 34; de Q Walker, Tax Wilderness, above $n 34$.

${ }^{45}$ Peter Grabosky and John Braithwaite, Of Manners Gentle (1986).

${ }^{46}$ New Zealand Inland Revenue Department, Taxpayer Compliance, Standards and Penalties (2001).
} 
management. ${ }^{47}$ On this view, tax administration is legitimated less in terms of applying the rule of law and more in terms of efficiently managing risk. Thus, tax administration is no longer about 'collecting every last cent', but rather about maximising returns upon public resources allocated to the tax administration function. ${ }^{48}$

From this risk management perspective, the appeal of responsive regulation is the promise of administrative cost savings and efficiency, notwithstanding a possible loss of some tax revenue. ${ }^{49}$ This efficiency can be achieved at a number of levels. First, the profession might take a less aggressive approach to advice resulting in less leakage of tax revenues. Second, certain functions traditionally exercised by the administrator might be effectively delegated or outsourced to the profession. On the other hand, the profession might justify such an approach for their clients on the basis of a compromise between the costs of a possible dispute with the tax authority and the desire to minimise tax payable.

However, this narrative of risk management cannot, of itself, sustain legitimacy. This is because the flexible administration which it embodies threatens to undermine public confidence in the integrity of the tax system. The adoption of risk management as a tax administration tool therefore means that the general public must also assume a risk management outlook in overseeing the administration of its tax system. The incorporation of risk management within the discourse of tax administration can therefore be expected to prompt public demands for enhanced transparency and accountability as the general public seeks to manage its risk in the form of threats to tax system integrity.

47 Christine Parker, The Open Corporation: Effective Self-Regulation and Democracy (2002). For a discussion of the application of Parker's work in the context of taxation law, see John Braithwaite, 'Meta Risk Management and Responsive Regulation for Tax System Integrity' (2003) 25 Law and Policy 1.

${ }^{48}$ Financial Management and Accountability Act 1996 (Cth).

${ }^{49}$ However, some would suggest that the more conciliatory approach adopted by the ATO in recent years has and will continue to lead to greater tax revenues: 'Carmody's Softly Softly Approach Delivers Windfall', Sydney Morning Herald (Sydney), 27 June 2006, 36. 


\section{THE PARTNERSHIP MODEL}

\section{ISSUES WITH THE PARTNERSHIP MODEL}

In the preceding Part, the ideological drivers for the introduction of the responsive regulation model were noted. It was argued that responsive regulation was perceived to offer the most appropriate way forward for tax administrators confronting an array of often conflicting pressures. The purpose of this Part is to critically reflect upon the challenges which must be addressed if responsive regulation is to live up to its promise. In earlier papers, the writers have explored the issues that arise with the partnership model in the Australian context. ${ }^{50}$ These issues are summarised in the following paragraphs.

\subsection{Do the Partners Share a Common Interest?}

The notion of a partnership suggests that the partners are in pursuit of a common interest. This common interest might arise because the partners share a common moral standpoint such as 'paying taxes is a good thing to do' or because they agree upon the meaning of the law and share an interest in seeing that meaning fulfilled.

\subsubsection{A Common Moral Standpoint?}

Although there are many who subscribe to the existence of an underlying communal consensus (for example, Rousseau's concept of the general will or Lipset's moral consensus), the existence of such consensus is contested. In particular, some strands of neo-liberalism adopt a strong view of individualism in arguing that taxation imposed under laws made without the consent of the particular taxpayer is theft. ${ }^{51}$ This individualism limits the prospect

\footnotetext{
${ }^{50}$ See, eg, Dabner, above $n 11$.

${ }^{51}$ See, eg, Eric Mack, 'Self-Ownership, Taxation, and Democracy: A PhilosophicalConstitutional Perspective' in Donald Racheter and Richard Wagner (eds), Politics, Taxation, and the Rule of Law (2002) 9; Robert Nozick, Anarchy, State and Utopia (1974). For a discussion of the vicissitudes of this discourse, see Marc Linder, 'Eisenhower-Era Marxist Confiscatory Taxation: Requiem for the Rhetoric of Rate Reduction for the Rich' (1996) 70 Tulane Law Review 905.
} 
of any 'thick' social consensus upon the common will because it is most unlikely that universal consent will be achieved in relation to taxation.

This conflict is evident in the literature regarding tax ethics, where the nature of the profession's obligation to the tax system is a vexed question. ${ }^{52}$ In this domain, it is generally accepted that tax advisers are ethically obligated to ensure that they uphold 'the law'. However, for the reasons noted below, there is no universally accepted interpretation of what such an injunction entails, particularly in cases of uncertain or indeterminate law. Indeed, a review of the ethical standards applicable to those fulfilling tax adviser functions demonstrates considerable variance in the wording of ethical rules across different types of adviser function ${ }^{53}$ and also across different jurisdictions. Thus, for example, the United States manual on tax practice standards acknowledges the distinction between an advocate, whose paramount duty is to zealously represent a client, and an adviser, whose pursuit of their clients' interests may be constrained by a duty to see that the tax system is not improperly used by the taxpayer. The relative weightings of the conflicting interests may, thus, depend upon the exact role being played by the adviser. ${ }^{54}$ Further, the nature of ethical standards adopted by different professional bodies varies. ${ }^{55}$ This debate regarding ethical standards

52 Discussed in Dabner, above n 11. At least one New Zealand tax practitioner does not believe that it is in the domain of a tax adviser to consider the morality of a transaction: David Simcock, 'The Tax Professional: Responsibilities and Exposures' (1994) 28 Taxation in Australia 549. Certainly, the New Zealand Law Society ethical rules would appear to confirm the view that there is no obligation to the tax system.

${ }^{53}$ Functions range from preparing tax returns and managing tax audits through to tax planning and dispute resolution. Furthermore, the profession itself is eclectic, ranging from tax agents and suburban accountants through to international tax advisers, tax lawyers and tax barristers.

${ }^{54}$ Bernard Wolfman, James Holder and Kenneth Harris, Standards of Tax Practice $\left(5^{\text {th }}\right.$ ed, 1999) [49]-[52].

${ }^{55}$ Maria Italia, 'Ethics and Tax Practitioners: Accountants and Lawyers' in C Evans and A Greenbaum (eds), Tax Administration: Facing the Challenges of the Future (1998) 281-2 (arguing that accountants' ethical obligations serve to constrain their 


\section{THE PARTNERSHIP MODEL}

has come to the fore in Australia recently, with the debate over the Commissioner's proposed 'dob-in' line for tax agents ${ }^{56}$ and the issue of the draft code of professional conduct. ${ }^{57}$ Tax advisers argue that their fundamental obligation must always be to their clients and it is inconceivable that they could also act as the Commissioner's spy.

If it is, indeed, the case that tax advisers' obligations to uphold the law should be interpreted from an individualist standpoint, then 'upholding the law' means assisting the client to further their individual interest by minimising their tax liability while remaining 'within the law'. Although this might be considered selfish and lacking in public spirit, for those who at least express an acute sensitivity to the threat of state oppression, keeping the state to its proper amount of tax is in the public interest because it serves to constrain state 'interference' in private markets. Such an outlook does not bode well for partnership relations if the tax administrator

tax planning role, by contrast to lawyers' more general and adversarial planning standards).

${ }^{56}$ Referred to in Michael D'Ascenzo, 'The ATO's Approach to Tax Administration' (Speech delivered at the Taxpayers Australia and Superannuation Australia Annual Conference 2006, Sydney, 10 November 2006). This met with resistance from elements of the profession: Elizabeth Kazi, 'Tax Dob-in Line on Hold', The Australian Financial Review (Sydney), 27 November 2006, 1; Editorial 'ATO Needs Better Laws, Not Informers', The Australian Financial Review (Sydney), 9 October 2006, 70. Nevertheless, the ATO subsequently implemented the initiative with the Commissioner at pains to emphasise that it was the profession's idea in the first place: Michael D'Ascenzo, New Integrity Phone Service for Tax Agents (2007) Australian Government - Australian Taxation Office <www.ato.gov.au/print.asp? doc $=/$ content/00093540.htm $>$ at 27 February 2007. But see Elizabeth Kazi, 'Tax Agents Wary of ATO's "Dob-in" Line', The Australian Financial Review (Sydney), 28 February $2007,8$.

57 This code is part of the proposed new tax agents regime issued for comment in May 2007. See generally Treasury, Exposure Draft Tax Agent Services Bill, Related Regulations and Explanatory Material (2007) <http://www.treasury.gov.au/ contentitem.asp?NavId $=037 \&$ ContentID $=1218>$. The code is to be established by proposed s 604-10. This provision contains motherhood statements that could be interpreted as stating a stronger obligation on tax practitioners towards maintaining system integrity. See also Michael D'Ascenzo, 'Do Professionals Have an Ethical Compass and Does It Matter?' (Speech to the Victorian Tax Bar Association, Melbourne, 29 March 2007). 
adopts a revenue maximising stance. It also raises doubts as to the motives of tax advisers who purport to embrace the partnership model.

On the other hand, if the ethical obligation to uphold the law is taken to impose an obligation on the profession to assist the tax administrator in maximising government revenue, this entails a narrow reading of the duties of loyalty and confidentiality of tax advisers to their clients. ${ }^{58}$

\subsubsection{A Shared Understanding of the Law's Meaning?}

Acknowledging that the 'partners' may not share a common moral standpoint does not necessarily spell the end for the prospect of a tax partnership. Drawing upon various liberal legalist theories of law, the partnership model might be grounded upon a common interest framed in terms of upholding formal legal justice. That is, it might be contended that the partners share a common interest in ensuring that the 'correct' amount of tax is paid.

\subsubsection{Indeterminate Law?}

However, this contention assumes that there is, in fact, a 'correct' amount of tax payable that can always be identified, a proposition which is hotly contested. The meaning of taxation law is not just uncertain, it is indeterminate. It is indeterminate in the sense that no one can declare that they have found the right answer such that all other possible interpretations are obviously flawed. Only in such circumstances might a critical consensus emerge. Such indeterminacy arises because different interpretative methodologies

\footnotetext{
${ }^{58}$ The conflicting demands on tax agents and the need to provide them with greater guidance and protection if a partnership relationship with the ATO was to be progressed were the findings of Pauline Niemirowski and Alexander Wearing, 'Do Australian Taxation Office Staff and Compliant Taxpayers Identify with Tax from the Same Perspective, or are There Significant Degrees of Separation?' (2006) 9(2) Journal of Australian Taxation 119.
} 


\section{THE PARTNERSHIP MODEL}

or different interpretative standpoints (or both) might be adopted. ${ }^{59}$ Although we live in an era where the purposive rule of statutory construction purportedly enables us to identify the true legal meaning, there are good reasons to question this proposition. There are different understandings of 'legislative purpose' and in many cases the legislative purpose is vaguely stated. The Australian small business capital gains concessions, for example, are said to have been enacted in order to 'reduce the tax burden of small business' and to simplify the law. Such statements of purpose offer no assistance in determining the meaning of 'retirement' for the purposes of s 152-105 of the Income Tax Assessment Act 1997 (Cth) ('the ITAA97'). ${ }^{60}$

Judges arrive at different interpretations of statutes simply because there are so many alternate paths which they might choose to follow in identifying what they consider to be the meaning of legislation. Taxation laws, then, are inherently ambiguous and opportunities for dispute as to the tax payable arise in all but the simplest tax profiles. ${ }^{61}$ The reality is that only a portion of these disputes is identified or litigated for all sorts of reasons: the matter might not come to the attention of the tax administrator, taxpayers or tax administrator (or both of them) might decide to ignore the matter, or some strategic interpretation might be adopted by the tax administrator which obviates dispute with respect to a particular matter. Even if it is conceded that the meaning of the law is indeterminate in just some instances, conceiving of a common interest in terms of identifying the 'correct' amount of tax is misconceived.

\footnotetext{
${ }^{59}$ Mark Burton, 'Responsive Regulation and the Uncertainty of Tax Law: Time to Reconsider the Commissioner's Model of Cooperative Compliance?' (2007) 5(1) eJournal of Tax Research 71.

${ }^{60} \mathrm{See}$, eg, Board of Taxation, A Post-Implementation Review of the Quality and Effectiveness of the Small Business Capital Gains Concessions in Division 152 of the Income Tax Assessment Act 1997: A Report to the Treasurer (2005) 4.

${ }^{61} \mathrm{M}$ Burton, 'The Rhetoric of Tax Interpretation: Where Talking the Talk Is Not Walking the Walk' (Paper presented at the $17^{\text {th }}$ Annual Australasian Tax Teachers Association Conference, Wellington, 27 January 2005).
} 


\subsubsection{Determinate Law but We Are Uncertain about What the}

\section{Law Is}

However, for the sake of argument, let us assume that there is one correct meaning of the taxation law 'out there', awaiting discovery by a superhuman judge such as Dworkin's Hercules. ${ }^{62}$ Does that make a difference in terms of the partnership model? The short answer is 'no', because even Dworkin admits that Hercules is superhuman. ${ }^{63}$ This means that in our second best world there will be at least some cases where the 'partners' will disagree about the appropriate interpretation of particular legislation. Even if they agree that they are both seeking the 'right' statutory meaning, and even if they agree upon the same interpretative standpoint and methodology, it is reasonable to expect that they will inevitably disagree in at least some cases about the appropriate outcome. For example, although the Commissioner has already adopted a generous reading of ITAA97 s $152-105,{ }^{64}$ there will be those who will continue to press their self-interest by, for example, arguing that the disposal of an asset well in advance of actual retirement is nevertheless 'in connection with retirement'.

\subsection{Problems Raised by Conflicting Interests}

\subsubsection{The Continuation of Adversarialism}

The existence of conflicting interests within the partnership destabilises that partnership, as instances of adversarialism on both sides threaten the development of trust. Such instances of adversarialism can be overt, as in the case of the Commissioner's response to the decision in Essenbourne Pty Ltd $v$ Federal Commissioner of Taxation, ${ }^{65}$ a response which recently attracted strong criticism from the Full Federal Court in Federal

\footnotetext{
${ }^{62}$ Ronald Dworkin, Law's Empire (1986).

${ }^{63}$ Ibid 265.

${ }^{64}$ Australian Taxation Office, Advanced Guide to Capital Gains Tax Concessions for Small Business (2006).

${ }^{65} 2002$ ATC 5201.
} 


\section{THE PARTNERSHIP MODEL}

Commissioner of Taxation v Indooroopilly Children Services (Qld) Pty Ltd. ${ }^{66}$ Similarly, this adversarialism is evident in taxpayers 'playing for the grey'. 67

Adversarialism can also be more subtle, as in the case of the understanding of 'compliance' adopted for the purposes of the cooperative compliance model. This understanding of compliance also reflects an essentially neo-liberal worldview. Neo-liberalism places considerable faith in individuals to ensure that they are adequately informed before making resource allocation decisions. This assumption of individual responsibility underpins the defensive outlook of tax administrators in framing the tax compliance discourse. In the context of tax administration, the assumption that individuals know how much to invest in managing their tax risk means that the tax compliance literature has, almost invariably, ${ }^{68}$ focused upon taxpayer under-compliance and ignored taxpayer over-compliance because taxpayers are assumed to ensure that they pay no more than is required by law.

The taxpayer compliance literature is therefore framed in terms of identifying the technologies for recovering revenue that would otherwise be lost by, for example, promoting taxpayer voluntary compliance. In this regard, the perceived failings of the erstwhile 'adversarial' approach encouraged consideration of alternate models of tax administration which better assured the protection of the revenue. It is therefore no coincidence that the pyramidal depiction of responsive regulation focuses upon strategies for dealing with taxpayer non-compliance: the base of the pyramid is the compliance baseline beneath which it is assumed no taxpayer goes. However, the

662007 ATC 4236, discussed in Elizabeth Kazi, 'ATO Drops Aggressive Legal Tactics', The Australian Financial Review (Sydney), 6 March 2007, 1; Elizabeth Kazi, 'Ruling May Go beyond the Fringe', The Australian Financial Review (Sydney), 6 March 2007, 6.

${ }^{67}$ Doreen McBarnet, 'When Compliance Is Not the Solution but the Problem: From Changes in Law to Changes in Attitude' in Valerie Braithwaite (ed), Taxing Democracy: Understanding Tax Avoidance and Evasion (2003) 229.

68 There are two exceptions of which we are aware. One is empirical research reported in J Roth, J Scholz and A Witte, Taxpayer Compliance (1989) vol 1, 51-4. 
literature which has recorded evidence of taxpayer over-compliance suggests that the responsive regulation model should be diamondlike. Under this diamond model, the top half of the diamond would be the existing compliance pyramid. The bottom half of the diamond would essentially be a mirror opposite to the top half, but with one crucial difference. By contrast to the reference to enforcement strategies in the top half of the diamond, the bottom half would refer to increasing strategies for preventing overpayment of tax. Adoption of the pyramidal form in the responsive regulation model, in spite of evidence of taxpayer over-compliance, therefore might be one illustration of Levi's theory of predatory rule. ${ }^{69}$

\subsubsection{Power, the Rule of Law and Public Accountability within the Partnership Model}

\subsubsection{The Presence of Power in Tax Administration}

The failure to appreciate that there is not necessarily a 'correct' view of the taxation laws challenges the partnership model. Moreover, it also exposes a weakness in the theory supporting voluntary compliance and responsive regulation. When the theory speaks of encouraging taxpayers to voluntarily comply to pay the 'correct' amount of tax, what it means is that the tax administrator is seeking to achieve voluntary compliance with its interpretation of the taxation laws, or at least the interpretation of the taxation laws which it is prepared to accept. Rather than the tax administrator merely being the neutral, disempowered oracle for the legislative voice, it exercises power in wielding its interpretative discretion.

\footnotetext{
${ }^{69}$ Margaret Levi, Of Rule and Revenue (1988) 3 ('Rulers are predatory, in the sense that they are revenue maximisers'). Notably, the Irish Revenue Commissioners have been urged by a parliamentary committee to devote more resources to ensuring that all tax reliefs are claimed, on the basis that the Commissioners have an equal duty to ensure that reliefs are claimed as well as tax is paid: Joint Committee on Finance and the Public Service, Houses of the Oireachtas, Interim Report on under-Claiming of Tax Credits, Allowances and Relief by Taxpayers (2007).
} 


\section{THE PARTNERSHIP MODEL}

\subsubsection{Administrative Interpretative Power and the Rule of Law}

This is not to say that the tax administration autonomously determines its interpretation of a particular rule and imposes it 'from above', as a centralised model of state power would suggest. Rather, all sorts of 'external' influences shape and interact with the 'internal' processes, ideas and institutions of the tax administrator to the extent that the internal-external dichotomy inaccurately depicts the social reality. ${ }^{70}$ It is difficult to see, for example, successive favourable administrative rulings regarding artificial schemes designed to generate favourable treatment of superannuation as anything but an example of the ATO internalising a desire to promote retirement savings by turning a blind eye to the potential application of the general anti-avoidance rule. ${ }^{71}$ A fundamental limitation of the partnership model, then, is the failure to take account of the fact that the partnership is not grounded upon determinate law. This is significant because the relationship of the partners revolves around the discretionary exercise of state power; in some cases the tax administrator will have the upper hand, while in other cases the taxpayer will have the upper hand.

However, it is unlikely that this rule of law discourse will be jettisoned any time soon, primarily because it is extremely beneficial to tax administrators in protecting the apparent impartiality of their function, ${ }^{72}$ and so frequent references to the role of tax administrators as mere rule appliers rather than rule makers can be found. ${ }^{73}$ In practice however, and for the reasons noted above, the administrator

\footnotetext{
${ }^{70}$ Bruno Latour, 'The Powers of Association' in J Law (ed), Power, Action and Belief: A New Sociology of Knowledge? (1986) 264.

${ }^{71} \mathrm{See}$, for example, the lenient treatment of superannuation recontribution strategies which are generally known as the superannuation magic pudding: Australian Taxation Office, 'Guidance on Recontributions to Superannuation' (Press Release, 4 August 2004).

72 Michael Carmody, 'Administering Australia's Tax System' (Speech delivered at the Monash University Law School Foundation Lecture, Melbourne, 30 July 1998). See also George Megalogenis, 'Cheats Lobbying Politicians to Pressure the ATO', The Australian (Sydney), 31 July 1998, 5.

${ }^{73}$ Australian Taxation Office, Integrity Framework (2006) 8.
} 
has some discretion in determining the appropriate interpretation of the relevant statute. The intersection of this interpretative discretion, the professed adherence to the rule of law and also the partnership model generate several nodes of tension.

\subsubsection{Administrative Interpretative Discretion and the Prospects of Partnership}

Although it is clear that the general law concept of partnership is not directly applicable to the 'partnership' between taxpayers and tax administrators, the general law understanding of partnership does reflect the common understanding of the partnership concept. The essence of partnership law is that the partners owe duties as between themselves, in particular a duty of good faith. In the context of a taxation partnership, for example, how should an administrator administer an ambiguous tax provision where, on the most likely interpretation of the provision, it would have what the tax administrator accepts is a draconian and harsh operation? Should it, as part of its partnership obligations, administer the law to achieve what it considers to be a substantively 'fair' result? Or is it bound to give effect to the most likely interpretation which complies with formal notions of justice (such as a 'purposive' construction, despite the difficulties of ascertaining the legislative purpose in many cases) and which, coincidentally, maximises government revenue? In either case, is it bound to advise the government to remove the inequity or does that go beyond its role of applying the law?

\subsubsection{Accountability}

In order to address legitimate concerns regarding unintended or mischievous legislative consequences identified by its partner, the tax profession, the tax administrator needs to be able to exercise some discretion and exhibit flexibility. The exercise of administrative interpretative discretion may work to the advantage of taxpayers directly affected (ie a favourable exercise of discretion is adopted by the administrator). In such cases, the general public has an interest in ensuring that the administrator is not being unduly lenient or non-neutral (or both) in its exercise of this interpretative 


\section{THE PARTNERSHIP MODEL}

discretion. Overt recognition of administrative flexibility by the Commissioner therefore generates an imperative for alternate means of assuring community confidence in the tax administration. Here, again, the hand of the neo-liberal discourse can be seen: it is enough, it is said, for government to 'transparently' report its actions such that government is ultimately held accountable for those actions. ${ }^{74}$

As originally conceived, responsive regulation entailed a tripartite negotiation of regulatory outcomes between the regulator, the regulatee and a community representative. ${ }^{75}$ The role of the latter was to provide assurance to the community that regulatory outcomes consonant with the public interest were achieved. However, in the context of taxation law, secrecy obligations have dictated the adoption of a bipartite model of regulatory negotiation. In such a model of discretionary decision making 'behind closed doors', it behoves the tax administrator to be very careful to identify and explain the basis for any concessional position it adopts, or it could damage its legitimacy and detract from the goal of encouraging voluntary compliance. Corruption, regulatory capture, incompetence and oppressive conduct can all too readily thrive in such an environment. Over the short history of the implementation of the responsive regulation model within the tax domain, it is therefore no surprise that tax administrators in both Australia and New Zealand have adopted measures designed to open the processes of tax administration to public scrutiny. The public rulings panel, the ATO Integrity Adviser, ${ }^{76}$ the Part IVA panel, ${ }^{77}$ the public involvement in

\footnotetext{
${ }_{75}^{74}$ Commonwealth of Australia, Making Transparency Transparent (1999).

${ }_{76}^{75}$ Ayres and Braithwaite, above $n$ 35, 57-8.

76 Australian Taxation Office, Integrity Framework, above n 73, 9 and Commissioner of Taxation, Annual Report 2005-06 (2006) 208-9 include some basic information regarding membership and the function of the committee. However, the annual report does not provide detail of matters considered by the committee nor of action items initiated by the committee.

77 Australian Taxation Office, Practice Statement Law Administration PS LA 2005/24 (2005).
} 
the management of test case funding ${ }^{78}$ and the recent practice of publishing (albeit limited) aggregated data regarding tax dispute settlements ${ }^{79}$ are just some instances of ad hoc measures introduced in an effort to buttress community confidence.

It is difficult to see where this accretion of public oversight measures will stop, as the Commissioner will continue to face pressure to defend every decision making process by introducing some measure to assure community confidence in the integrity of the tax administration. To illustrate the relentless and ongoing mandate for additional information to validate ATO decisions, consider the data regarding the settlement of tax disputes which were published for the first time in the Commissioner's 2006-07 Annual Report. Unfortunately this data provides little information which assists the general community in forming a judgment as to the integrity of procedures. It would be useful to know, for example, the breakdown of the disputes in terms of the particular legislation concerned, the profile of the taxpayers concerned (ie small business, individuals by income profile, large business, etc), whether the same taxpayers had benefited from earlier settlements and to have more information as to why the settlement was allowed (ie if for want of information, what was the cause of the lack of information with a view to ascertaining whether legislative reform is appropriate). ${ }^{80}$

Introduced as a means of better achieving legislative objectives by arming tax officers 'in the field' with a discretion to select the

78 For details of which, see Australian Taxation Office, Test Case Litigation Program: How to Apply for Funding (2005). Note that the operation of this program was reviewed by the Inspector-General of Taxation: Inspector-General of Taxation, Review of Tax Office Management of Part IVC Litigation: A Report to the Minister for Revenue and Assistant Treasurer (2006).

${ }^{79}$ Commissioner of Taxation, above $\mathrm{n} 76,171$.

${ }^{80}$ Further integrity measures in the context of settlements include Australian Taxation Office, Code of Settlement Practice (2007) and the issue of practice statements, especially Australian Taxation Office, Practice Statement Law Administration PS LA 2007/5 (2007) and Australian Taxation Office, Practice Statement Law Administration PS LA 2007/6 (2007), identifying the lengths to which the ATO has gone in an effort to ensure consistency and transparency. 


\section{THE PARTNERSHIP MODEL}

most appropriate regulatory response, the cooperative compliance model is in danger of collapsing under the weight of more and more integrity assurance measures. Rather than being dealt with 'on the ground', more and more measures will have to be referred 'up the chain of responsibility' for consideration by a quality assurance panel. Further, the Commissioner will feel obliged to gather and disclose more data in an effort to validate the integrity of his decisions. Gathering and publishing such data, installing public panels, engaging with the plethora of external review bodies which quiz the Commissioner regarding his discretionary authority all add to the cost of tax administration. The 'small state' promise of responsive regulation is also quite likely to be contested. Although it is impossible to compare the administrative compliance costs of one tax period to those of another period owing to the infinite variables involved, it is at least true to say that Australian administrative compliance costs have not declined as a percentage of tax revenue raised.

\subsection{Application Issues}

There can be no doubting the force of repeated statements of senior ATO staff who uniformly espouse the virtues of the partnership paradigm. However, the experience in Australia would appear to be that the ATO has been patchy in its application of the partnership model. There are a number of causes of this phenomenon.

The first stems from the fact that the cooperative compliance model incorporates disparate and sometimes competing imperatives at different levels. Thus, at the thematic or discursive level, responsive regulation incorporates the often contradictory discourses of neo-liberalism and welfarism. Neo-liberals find many aspects of the model appealing (as discussed in Part 2.3 above), while welfarists also applaud the promise of enhanced revenue arising from efficient tax administration. At the pragmatic level, the 'one size fits all' dictates of the rule of law are diametrically opposed to the imperative of understanding particular taxpayer conduct in its own particular 
context. Resolution of these conflicts can be no easy task for tax administrators at all levels and in quite different contexts. Such difficulties are only compounded by the vagaries of the legislation. The Commissioner professes reliance upon the legislative purpose, ${ }^{81}$ but as discussed above, in many cases this does not provide a firm basis for administrative action. It is therefore to be expected that differences of approach will exist across a tax administration agency.

The second cause is that the ATO is experiencing difficulty in having the model accepted at all levels within the organisation and in all contexts. ${ }^{82}$ It bears repeating that responsive regulation constitutes a massive cultural shift, particularly for an organisation which, daily, encounters egregious tax minimising behaviour. It would therefore be understandable for some ATO operatives to adopt a posture of resigned acceptance of the new partnership paradigm. For some ATO operatives, and perhaps just in some contexts, the partnership model might be mere rhetoric to be employed in the adversarial combat in which they are engaged with the profession. There also would appear to be a cohort of the profession who are reluctant to acknowledge any duty to the system and so are hardly likely to embrace the spirit of a partnership relationship with the ATO. To them, the partnership rhetoric is simply a subterfuge or strategy to further the interests of their clients.

However, it also appears that the concern for integrity discussed above has meant that field officers may be unable or reluctant to implement the responsive regulation model. Interviews with Australian practitioners suggest that internal policies and structures within the ATO restrict the authority of lower level staff to provide the flexibility and decision making ability necessary for the effective implementation of the partnership model. ${ }^{83}$

\footnotetext{
${ }^{81}$ Australian Taxation Office, Integrity Framework, above n 73, 8 .

82 Elizabeth Kazi, 'ATO Ignores Criticism, Plays It Tough', The Australian Financial Review (Sydney), 10 November 2006, 59.

${ }^{83}$ See the discussion below, and see also comments by the President of the Taxation Institute of Australia in Andrew Mills, 'President's Report: Moving towards an Efficient and Effective Tax System - Improving Our Members' Experience with
} 


\section{THE PARTNERSHIP MODEL}

Whilst the ATO's administrative and interpretative discretions referred to earlier provide the basis for the flexibility mandated by the partnership model, a third source of application difficulties may be the real or perceived limits of these discretions. The Commissioner has acknowledged the limitations of his discretionary powers to enter into negotiated and practical outcomes with taxpayers and the profession. ${ }^{84} \mathrm{~A}$ failure to respond to practitioner concerns on the basis of an absence of power is invariably accompanied with the refrain that the ATO only applies the law made by Parliament. Yet on other occasions the ATO may not appear as restrained. ${ }^{85}$ This inconsistency generates tensions and fuels the calls for greater transparency, itself a stress point given privacy and confidentiality constraints. Nevertheless, it is conceded that the ATO's discretionary powers do have limits, albeit that they are poorly defined.

The fourth cause is that the introduction of the responsive regulation model has not been guided by a carefully developed policy which was the subject of open consultation and which is the centrepiece of the ATO administrative model. Rather, different aspects of responsive regulation have been dealt with on an ad hoc basis as various crises have emerged. The result is that it must be extremely difficult for ATO staff to have a clear understanding of the meaning of responsive regulation, its operational incidents, the threats and benefits which it poses and the ATO efforts to respond to the threats and maximise the benefits. This is not to say that there is

the ATO' (2006) 41 Taxation in Australia 133, 133 ('Our members' experience shows that the level at which ATO officers have discretion or ability to give advice and make decisions, is not as high as it once was ... many tasks have to be referred elsewhere for action').

${ }^{84}$ Michael D'Ascenzo, 'Consolidation: Making Choices - Risk Management in Action' (Paper presented at the 2004 Corporate Tax Association Convention, Sydney, 3 May 2004).

${ }^{85}$ An excellent example is provided by the recent Australian Taxation Office, Practice Statement Law Administration PS LA 2007/11 (2007), where the ATO outlines circumstances where the superannuation guarantee charge will not be imposed upon late payment of contributions notwithstanding the express recognition that the legislation confers it with no discretion in this regard. 
no publicly available ATO literature regarding its adoption of responsive regulation, but it is to say that that literature is fragmented and incomplete. Thus, promoting voluntary compliance is the centre of the Commissioner's compliance strategy, ${ }^{86}$ while assuring community confidence in the integrity of the tax administration is dealt with in the Commissioner's annual reports and an assortment of other publications, ranging from practice statements to speeches delivered by senior ATO staff. A coherent and current statement of what responsive regulation means to ATO practice and management would be extremely beneficial in enhancing the homogeneity of responsive regulation throughout the ATO.

\section{CONCLUSION: WHERE DOES THE FUTURE OF THE PARTNERSHIP MODEL LIE?}

Intuitively, the partnership model of tax administration promises much more than any adversarial model in terms of tax system efficiency. However, the preceding discussion of the partnership model illustrates the point that it is not possible to draw a clear dichotomy between an adversarial model and a partnership model. Rather, it has been suggested that there are emanations of adversarialism within the partnership model which threaten to destabilise that model and undermine the efficiency gains that simplistic depictions of the model might suggest. Thus, for example, the indeterminacy of taxation law undermines the mutuality of purpose that the concept of a partnership connotes. In the absence of the guiding hand proffered by mutual agreement upon a common object, myriad factors will play upon the minds of actors in shaping their actions. In this dynamic environment it is reasonable to expect that individual self-interest or state predatory rule will prevail, but the existence of contest will call into question the accuracy of the partnership model.

The fact that the partnership model cannot rid itself of adversarial contests suggests that future, independent research should

${ }^{86}$ Australian Taxation Office, Compliance Program, above n 13. 


\section{THE PARTNERSHIP MODEL}

be directed towards assessing the experience of the partnership model 'on the ground'. As discussed at the end of Part 3 above, preliminary discussions with tax practitioners in both Australia and New Zealand suggest that the operation of the partnership model presents significant challenges. These challenges might be categorised as cultural or ideological (or both), and also systemic. Further research needs to be undertaken with a view to assessing the relative significance of these challenges as threats to the sustainability of the partnership model.

As suggested by the discussion of the ideological drivers behind the partnership model in Part 2 above, the partnership model answered many of the concerns of an emergent neo-liberal philosophy. However, neo-liberalism posits the opposition of the individual and the state, and therefore threatens the viability of the partnership model. The extent to which the opposition between state and individual has been moderated by the partnership model is therefore crucial to the success of the partnership model. If adversarialism remains as a significant force in shaping the relationship between taxpayers and tax administrators, the future of the partnership model must be assessed. On the other hand, if the partnership model has dampened adversarialism, a critical review of the mechanisms that have achieved this ideological shift would represent a significant contribution to the tax administration literature and also to the literature of social science more generally.

The systemic challenge to the partnership model centres upon the existence of administrative discretion which the partnership model proposes, but which the twin forces of the rule of law and administrative accountability reject. Further research is required with a view to identifying the extent to which the partnership model actually allows administrative discretion at all levels of the tax administration and the success of accountability systems in assuring administrative probity in the exercise of that discretion. 